\title{
The Effect of Board Structures on Financial Performance in Family Businesses: The Case of Borsa Istanbul in Turkey ${ }^{1}$
}

\author{
Aylin POROY ARSOY iD a Yasemin ERTAN iD b Tuba BORA KILINÇARSLAN iD olcay BEKTAŞ iD d \\ a Bursa Uludag University, Faculty of Economics and Administrative Sciences, Bursa, Turkey. aporoy@uludag.edu.tr \\ b Bursa Uludag University, Faculty of Economics and Administrative Sciences, Bursa, Turkey. yasertan@uludag.edu.tr \\ c Bursa Uludag University, Faculty of Economics and Administrative Sciences, Bursa, Turkey. tubabora@uludag.edu.tr \\ d Bursa Uludag University, Faculty of Economics and Administrative Sciences, Bursa, Turkey. olcaybektass@gmail.com
}

\begin{tabular}{ll}
\hline ARTICLE INFO & ABSTRACT \\
\hline Keywords: & $\begin{array}{l}\text { Purpose - The aim of this study is to analyze the relationship between the structures of the board of } \\
\text { directors and financial performances of family businesses listed on the Borsa Istanbul. }\end{array}$ \\
Family businesses & Design/methodology/approach - In this study, in parallel with the report of the European \\
Corporate governance & $\begin{array}{l}\text { Commission, if the entrepreneur who established or acquired the firm (share capital) or their families } \\
\text { or descendants possess } 25 \text { percent of the decision-making rights mandated by their share capital, the } \\
\text { business has been accepted as a family business. As the determinants of the board structure of the } \\
\text { Financial performance } \\
\text { borsa Istanbul }\end{array}$ \\
rate in the board and the women member rate in the board were used. Benefiting from the previous \\
research, financial performances of businesses are measured by return on assets (ROA), return on \\
equity (ROE), return on sales (ROS) and leverage (LEV). A total of 160 family businesses (except \\
financial institutions) in Borsa Istanbul which can be reached board structure of businesses are \\
included in the scope of the research. Data on the board structures and financial performances of \\
businesses belong to January 1-December 31, 2018. The relationship between the board structures \\
and financial performances of family businesses has been tested by regression analysis. \\
Revised 9 July 2020 \\
Accepted 13 August 2020
\end{tabular}

\section{INTRODUCTION}

Family businesses are businesses that are frequently encountered all over the world. According to European Union reports, $50 \%$ of companies in the world, more than $60 \%$ of all Europe and $90 \%$ of companies in America are family businesses. $42 \%$ of the billionaires list published by Forbes in 2016 are family businesses. In Turkey, $95 \%$ of businesses are family businesses. This situation reveals the importance of the impact of family businesses on the world economy (Akbank et al., 2016:4). Family businesses are important, not only because they make an essential contribution to the economy, but also because of the long-term stability they bring, the specific commitment they show to local communities, the responsibility they feel as owners and the values they stand for (European Commission, 2009:4).

While the importance of family businesses throughout the world is so clear, implementing corporate governance in family businesses is a very important process for family businesses to maintain their activities in a stable manner and to use their resources effectively and efficiently. In our country, based on the

\footnotetext{
${ }^{1}$ This study was supported by The Commission of Scientific Research Projects of Bursa Uludag University, Project Number: KUAP(I)2015/74.

\section{Suggested Citation}

Poroy Arsoy, A., Ertan, Y., Bora Kılınçarslan, T., Bektaş, O. (2020). The Effect of Board Structures on Financial Performance in Family Businesses: The Case of Borsa Istanbul in Turkey, Journal of Business Research-Turk, 12 (3), 2531-2542.
} 


\section{A. Poroy Arsoy- Y. Ertan - T. Bora Kılınçarslan- O. Bektaş 12/3 (2020) 2531-2542}

Organization for Economic Co-operation and Development's (OECD) corporate governance principles and adapted to Turkey's conditions, corporate governance principles have been identified by the Capital Markets Board (CMB) including primarily publicly listed companies, all companies operating in the private and public sector. Corporate governance principles based on the principles of fairness, transparency, accountability and responsibility enable the professional management of businesses and the sustainability of businesses.

The following advantages can be taken by family business benefiting from corporate governance principles: (TKYD, 2009:15-16)

- Performance transparency of professional managers,

- Remuneration based on performance and fair market conditions,

- The career development pathways are not blocked by family members,

- Professionals and family members are subject to the same performance system,

- By responding to expectations such as determining the areas of authority and responsibility in decision making, it is possible to bring talented managers into the company.

Professional management of family businesses and taking strategic decisions depend on the boards of businesses. Therefore, the board structures to be established in the enterprises should work to ensure the sustainability of the business by considering the interests of the business. In this study, it is aimed to determine whether there is a relationship between the board (board of directors) structures established in family businesses and their financial performances.

\section{DEFINING FAMILY BUSINESSES}

Family businesses account for two-thirds of all businesses around the world, generating over $70 \%$ of annual global Gross Domestic Product (GDP) (Family Firm Institute, 2017). Across Europe, there are several definitions of family businesses made by academics, industry associations, and government institutions. These definitions mainly require major family influence in ownership and management.

According to Barry (1975:42), family business is an enterprise which, in practice, controlled by the members of a single family. Lansberg and Astrachan (1994:39) expand this definition and define the family business as a company that is owned or controlled by a family and in which one or more relatives is involved with management. On the other hand, family businesses can be defined as the businesses established by people with kinship ties to for the purpose of making a profit by producing goods and services (Erkan, 2012:5).

According to Donnelly (1964:94), a company is considered a family business when it has been closely identified with at least two generations of a family and when this link has had a mutual influence on company policy and on the interests and the objectives of the family. Such a relationship is indicated when one or more of the following conditions exist:

- Family relationship is a factor, among others, in determining management succession.

- Wives or -children of present or former chief executives are on the board of directors.

- The important institutional values of the firm are identified with a family, either in formal company publications or in the informal traditions of the organization.

- The actions of a family member reflect on or are thought to reflect on the reputation of the enterprise, regardless of his formal connection to management.

- The relatives involved feel obligated to hold the company stock for more than purely financial reasons, especially when losses are involved.

- The position of the family member in the firm influences his standing in the family.

- A family member must come to terms with his relationship to the enterprise in determining his own career.

On the other hand, Karpuzoğlu (2002:19) defines the family business as a company that was established in order to provide a livelihood for the family and/or to prevent the dissolution of the heritage, managed by the person who provides for the family, filled by family members of an important part of the management levels, 


\section{A. Poroy Arsoy- Y. Ertan - T. Bora Kılınçarslan- O. Bektaş 12/3 (2020) 2531-2542}

family members are largely influential in making decisions and at least two generations from the family are employed by the business.

As it is seen, three criteria are generally used in defining the family business. First, in a family business there is significant ownership, in that the family owns all or controlling share of the firm. Second, there is significant family involvement in management. Third, ownership and leadership are expected to pass to future family generations (Athanassiou et al, 2002:140).

According to the Ankara Chamber of Industry (2005:4), the family business is a company where at least two generations work in the organization, whose purpose is to sustain the welfare of the family, and / or to prevent the disintegration of the heritage. Moreover, owners often are responsible for the welfare of the whole household, and also manage the company. Family members are significantly involved in management or largely influence the decision-making in the business.

According to the European Commission definition (2009:10), a business is considered a family business when:

- The majority of decision-making rights is in the possession of the natural person(s) who established the firm, or in the possession of the natural person(s) who has/have acquired the share capital of the firm, or in the possession of their spouses, parents, child or children's direct heirs.

- The majority of decision-making rights are indirect or direct.

- At least one representative of the family or kin is formally involved in the governance of the firm.

- Listed companies meet the definition of family enterprise if the person who established or acquired the firm (share capital) or their families or descendants possess 25 per cent of the decision-making rights mandated by their share capital.

Although in the report of the European Commission, a business which at least $25 \%$ of the capital of publicly listed companies is owned by a family or under the control of a family is accepted the family business, it is seen that different criteria are used in defining public listed companies as family businesses when the studies in the literature is examined. Poutziouris et al. (2015) and Saidat et al. (2019), in their studies, $10 \%$ and more of the company accepted the businesses that belong to a family as family businesses. In the study of Al-Ghamdi and Rhodes (2015), a firm where the family has ownership of a minimum of $10 \%$ of the equity of the firm, and at least one representative of the family is a member of the management board is defined as a family business. Ibrahim and Samad (2011), Ling et al. (2016) and Kiziltoprak and Aksoy (2018), in their studies, businesses where all family members have at least 20 percent or more fraction of equity stake are classified as family businesses. On the other hand, Atılgan and Aynacı (2016), in their study, a firm where 30\% of a company's shares belong to a single family, Arosa et al. (2010) and Prencipe and Bar-Yosef (2011), in their studies, businesses where members of a family have $50 \%$ of voting rights are classified as family businesses. In the study of Donckels and Frohlich (1991), businesses in which family members own at least 60 percent of the equity are accepted as family businesses.

\section{CORPORATE GOVERNANCE IN CAPITAL MARKET BOARD OF TURKEY}

Corporate governance has come to the fore as a solution to financial crises and company scandals that emerged in the 1990s (Aktan, 2013:162). Thereupon, the OECD published the Corporate Governance Principles, which were not binding for governments and companies regarding to review their management approach and implement the determined standards in 1999. OECD first updated these principles in 2004 and then revised it. Finally, the updated G20/OECD Corporate Governance Principles were published at the meetings held in Ankara on 4-5 September 2015 by the G20 Ministers and Central Bank Presidents.

There is no universal definition of corporate governance. The reason for this is that the degree of adopting corporate governance has strong connections with the political, economic, cultural and social infrastructures of countries (Poroy Arsoy and Bora, 2015:32) According to the most common definition in the literature, corporate governance involves a set of relationships between a company's management, its board, its shareholders and other stakeholders. Corporate governance also provides the structure through which the objectives of the company are set, and the means of attaining those objectives and monitoring performance are determined (OECD, 2004:11). According to Ira M. Millstein, corporate governance refers to that blend of law, regulation and appropriate voluntary private-sector practices which enable the corporation to attract financial 


\section{A. Poroy Arsoy- Y. Ertan - T. Bora Kılınçarslan- O. Bektaş 12/3 (2020) 2531-2542}

and human resources, perform efficiently, and thereby perpetuate itself by generating long-term economic value for its shareholders, while respecting the interests of stakeholders and the society as a whole (World Bank, 2005:5). Another definition is that, corporate governance system is the combination of mechanisms which ensure that the management (the agent) runs the firm for the benefit of one or several stakeholders (principals). Such stakeholders may cover shareholders, creditors, suppliers, clients, employees and other parties with whom the firm conducts its business (Georgen and Renneboog, 2006:100).

Although corporate governance practices vary depending on the political, economic, cultural and social infrastructures of the countries, it is basically built on four principles. These are as follows; (SPK, 2003:3)

- Fairness: It means that the company management treats shareholders and stakeholders equally in all its activities and prevents possible conflicts of interest.

- Transparency: It refers to the exception of information that is of trade secret and not yet disclosed to the public, the disclosure of financial and non-financial information about the company to the public in a timely, accurate, complete, understandable, interpretable and easily accessible cost.

- Accountability: It expresses the obligation of the members of the board of directors to account against the stakeholders.

- Responsibility: It expresses the compliance of all the activities of the company management on behalf of the company with the legislation, articles of association and internal regulations and its auditing.

In Turkey, Corporate Governance Principles which based on the OECD corporate governance principles and prepared according to our country's own conditions, published by the CMB in 2003 and these principles was revised by $\mathrm{CMB}$ in parallel with the OECD updates. With these principles, it is aimed to introduce a management approach to the activities of private and public companies, especially publicly listed companies, continue their activities at international standards and thus to benefit from international financial resources with a more comfortable and cheaper cost to companies. Later on, the "Communiqué on Determination and Implementation of the Corporate Governance Principles (Serial: IV, No.54)" was published and entered into force in the Official Gazette dated November, 11th, 2011 and numbered 28081 (2nd repeated). With this communiqué, Corporate Governance Principles have ceased to be a principle decision. In the Official Gazette dated December, 30th 2011 and numbered 28158, the "Communiqué on Determination and Implementation of the Corporate Governance Principles (Serial: IV, No.56)" entered into force and the previous communiqué was repealed. This communique contains the regulations regarding the corporate governance principles to which the stock companies will be based. Various changes were made in this communiqué in 2012 and 2013 and the communique was revised. In addition, the Turkish Commercial Code No. 6102, which was published in the Official Gazette dated February, 14 th, 2011 and numbered 27846 and entered into force on July, 1st, 2012, brought innovations to companies in terms of corporate governance understanding. Finally, Series: IV, No.56 Communiqué was repealed and "Corporate Governance Communiqué (II-17.1)" entered into force in the Official Gazette dated January, 3rd, 2014 and numbered 28871.

The Corporate Governance Principles attached to the CMB Corporate Governance Communiqué (II-17.1) consist of a total of 97 principles under four sections (shareholders, public disclosure and transparency, stakeholders, board of directors). Publicly listed companies whose shares are traded on the stock exchange must comply with 24 of these principles. The remaining 73 principles are non- mandatory principles and the "comply or explain" approach has been adopted for these principles. With this approach, publicly listed companies, whose shares are traded on the stock exchange, are obliged to disclose their justification to the public in case they are not applied with information regarding whether these principles are applied. In Table 1 , the number of mandatory and non-mandatory principles of CMB Corporate Governance Principles is given in detail on the basis of section. According to this, 4 principles of the 24 principles in the shareholders section and 20 principles of the 45 principles in the board of directors section are mandatory. All of the principles included in the public disclosure and transparency section and the stakeholders section are non-mandatory principles. As can be seen, approximately three quarters of the CMB Corporate Governance Principles are voluntary. 
A. Poroy Arsoy- Y. Ertan - T. Bora Kılınçarslan- O. Bektaş 12/3 (2020) 2531-2542

Table 1. Distribution of CMB Corporate Governance Principles

\begin{tabular}{lccc}
\hline Principles of Corporate Governance & $\begin{array}{c}\text { Number of } \\
\text { mandatory } \\
\text { principles }\end{array}$ & $\begin{array}{c}\text { Number of non- } \\
\text { mandatory } \\
\text { principles }\end{array}$ & Total \\
\hline Shareholders & 4 & 20 & 24 \\
\hline Public Disclosure and Transparency & 0 & 6 & 6 \\
\hline Stakeholders & 0 & 22 & 22 \\
\hline Board of Directors & 20 & 25 & 45 \\
\hline Total & 24 & 73 & 97 \\
\hline
\end{tabular}

It is the duty of the board of directors to establish and implement a strong corporate governance framework (SPK, 2019:5). Therefore, board structures in companies play an important role in the effective implementation of corporate governance practices. The board of directors is included in the fourth section of the Corporate Governance Principles attached to the CMB Corporate Governance Communiqué (II-17.1). Within this section, there are ten principles regarding board structures. These principles can be summarized as follows: (SPK, 2014)

- The number of members of the board of directors is not less than five

- A majority of the members of the board of directors shall consist of members who do not have an executive duty

- There shall be independent members from among the non-executive board members

- The number of independent board members cannot be less than one third of the total number of board of directors and in any case, the number of independent board member shall not be less than two

- Independent members of the board of directors shall be up to three years and it shall be possible to nominated as a candidate and elected again

- Qualifications of independent board members

- The process of evaluating the independent board members

- The process when a situation that eliminates the independence of the independent member occurs

- The ratio of women members in the board of directors is not less than $25 \%$

- At least one of the members responsible for audit shall have a five-year experience on audit/accounting and finance.

Publicly listed companies whose shares are traded on the stock exchange must comply with the first eight of these principles. The principles regarding the women members in the board of directors and the professional experience of the committee members responsible for auditing are recommendations. In other words, these are non-mandatory principles and should be reported within the framework of the "comply or explain" approach.

\section{LITERATURE REVIEW}

With corporate governance practices gaining importance, studies involving companies' board structures and country examples are carried out. Spencer Stuart Board Index is an annual study that analyses composition, structure and governance practice of board of directors in major listed companies. First published over 30 years ago in the US, Board Indexes are produced in 22 countries (including in Turkey) around the world on an annual or biennial basis (Spencer Stuart, 2019). Heidrick \& Struggles Corporate Governance Report for 2014 revealed its corporate governance practices by making use of the data of 400 publicly listed companies, which include 15 countries in Europe (Heidrick \& Struggles, 2014). First published in 2014, The OECD Corporate Governance Factbook (the Factbook) supports the implementation of good corporate governance practices and boards of directors in the countries provide information on their structures. The Factbook is updated every two years (OECD, 2019). In Turkey, "BIST Yönetim Kurulları Araştırması (BIST Board of Directors Research) 


\section{A. Poroy Arsoy- Y. Ertan - T. Bora Kılınçarslan- O. Bektaş 12/3 (2020) 2531-2542}

2016" which examining in terms of formations, diversity and quantity of the board of directors in Borsa Istanbul listed companies was conducted research by the Corporate Governance Association of Turkey (TKYD, 2016). Also, in our country in 2018 in the European Reconstruction and Development Bank and Nestor Advisors cooperation "Kurumsal Yönetim İlkelerinin Uygulanmasında Sermaye Piyasası Kurulu'na Destek (Support to CMB for Implementation of Corporate Governance Principles)" within entitled project, a report has been prepared on the corporate governance structure and practices of publicly listed companies in Turkey (Avrupa İmar ve Kalkınma Bankası and Nestor Advisors, 2018).

When the national and international literature is analyzed, it is possible to come across many studies investigating the effect of companies' board composition, structures and diversity on financial performance. When these studies are examined, it is seen that different findings emerge. To summarize some of these studies; Erhardt et al. (2003) found that board of director diversity (gender and ethnic differences) was positively associated with both return on investment (ROI) and return on assets (ROA); Marimuthu (2008) found that board size and firm size positively influenced the level of performance in companies, however, ethnic diversity was proven to be an effective tool that should be imposed on boards of directors for a greater performance; Gordini and Rancati (2017) demonstrated both that the presence of at least one woman on a board of directors does not, alone, affect a firm's financial performance, and also that the gender diversity of a board does have a positive and significant effect on firm financial performance (Tobin's Q); Lee-Kuen et al. (2017) reached the result that a higher degree of female representation on the board of directors increases a firm's financial performance. Wellalage and Locke (2012) indicated that board gender diversity increases firm agency conflict while decreasing firm financial performance; in the meta-analytic reviews study conducted by Dalton et al. (1998), neither board composition nor board leadership structure has been consistently linked to firm financial performance; Kılıç (2014) showed that a positive relationship between the board size and firm performance (ROA), the rate of independent members on the board of directors affects the firm performance negatively, CEO duality, gender and national diversity on the board of directors have not significant impact on the firm performance; Carter et al. (2010) and Schank (2019) put forth that there is no impact of gender or national diversity on firm's financial performance; Aygün et al. (2011) showed that there is statistically significant negative correlation between corporate board size and firm debt ratio; Kao et al. (2019) showed that the higher the proportion of independent directors, the smaller the board size, together with a two-tier board system and no chief executive officer duality, the stronger the firm's performance; Şengür and Özbek Püskül (2011) showed that companies which have established both audit committee and corporate governance committee have higher returns, independent chairmen for all of its committee's and independent member in board have lower Return on Assets (ROA) and Return on Equity (ROE); Atılgan (2017) indicated that there is a weak and positive significant correlation between board size and ROA, ROE and EBITDA, while there is a weak and negative correlation between the ratio of independent board members and ROA and also a weak and negative correlation between the ratio of women in board and EBITDA margin and ROS.

Although there are many studies in the literature investigating the impact of companies' board structures on financial performance, these studies on family businesses are very few and different findings were obtained. Arosa et al. (2010), in their studies examining family SMEs that are not traded in the stock market in Spain, revealed that the presence of independents and affiliates on the board has a positive effect on performance when the firm is run by the first generation. However, they reached that when the firm is run by the second and subsequent generations, the presence of independents and affiliates has no effect on performance. Ibrahim and Samad (2011) examined the relationship of corporate governance mechanisms and performance between family and non-family ownership of public-listed firm in Malaysia. They found that family ownership showed a higher value than non-family ownership based on ROE, a strong relationship between firms with smaller boards and firm value. They also showed that the representation of independent directors in family firms does not improve firm performance. Al-Ghamdi and Rhodes (2015) examined the performance of companies listed in the Saudi Stock Exchange and compared family and non-family firms for ownership concentration, board size and CEO duality. They put forth that ownership concentration in family firms has a significant positive relationship with Tobin's $Q$, some evidence for a link between performance and board size in family firms, and CEO non duality is important for performance in family firms. Poutziouris et al. (2015), in their studies examining how family involvement affects the performance of UK companies listed on the London Stock Exchange, found that a non-linear relationship between family ownership and firm performance, with performance increasing until family shareholding reaches $31 \%$, at which point performance begins to decrease. 


\section{A. Poroy Arsoy- Y. Ertan - T. Bora Kılınçarslan- O. Bektaş 12/3 (2020) 2531-2542}

Moreover, they showed that the higher the involvement of the family in terms of management and governance, the higher the performance the firm appears to sustain over the long run and across generations. Ling et al. (2016) found that duality is positively significant to ROA in family firms which in Taiwan listed CSR. They also showed that for on family owned firms, board size is related to firm size, male gender, having more independent directors, and high CEO compensation, which all lead to better firm performance. Kiziltoprak and Aksoy (2018) compared the financial performance of family businesses traded on Borsa Istanbul with other businesses. They indicated that the return on equity was negatively influenced by the fact that a business is a family business. They also showed that the top manager of the company from family member negatively affected the return on equity as well as the ratio of the market value to the book value and the chairman of the board was from the family has not affected any of the performance criteria statistically significantly. Saidat et al. (2019) examined the relationship between corporate governance mechanisms and financial performance of family and non-family firms in Jordan. The study found that board size both in term of Tobin's $Q$ and ROA has a negative relationship with the performance of family firms. They also found some evidence for a relationship between performance and independent directors in family firms and ownership concentration in family firms has a negative and significant correlation with Tobin's $Q$.

\section{DATA AND METHODOLOGY}

The aim of this study is to analyze the relationship between the structure of board of directors (board structures) and financial performances of family businesses listed on the Borsa Istanbul. In this study, in parallel with the report of the European Commission, if the person who established or acquired the firm (share capital) or their families or descendants possess 25 percent of the decision-making rights mandated by their share capital, the business has been accepted as a family business. Taking into consideration the principles in the board structures in the CMB Corporate Governance Communiqué, as the determinants of the board structure of the businesses; the board size (total number of members), the non-executive member rate in the board, the independent member rate in the board and the women member rate in the board were used. Financial performances of businesses are measured by return on assets (ROA), return on equity (ROE), return on sales (ROS) and leverage (LEV). Determinants of board structures are independent variables and financial performance indicators are dependent variables. Descriptions and acronyms for dependent and independent variables are as in Table 2.

Table 2. Description and Acronym of Variables

\begin{tabular}{cll}
\hline \multicolumn{1}{c}{ Variables } & \multicolumn{1}{c}{ Acronym } & \multicolumn{1}{c}{ Description } \\
\hline \multirow{3}{*}{ Independent Variables } & SIZE & Board size (total number of members) \\
\cline { 2 - 3 } & NON-EXE & Non-executive member rate in the board (\%) \\
\cline { 2 - 3 } & INDPNT & Independent member rate in the board (\%) \\
\cline { 2 - 3 } Dependent Variables & WOMEN & Women member rate in the board (\%) \\
\hline \multirow{3}{*}{ ROA } & Return on assets (Net income/total assets) \\
\cline { 2 - 3 } & ROE & Return on equity (Net income/total equity) \\
\cline { 2 - 3 } & ROS & Return on sales (Net income/net sales) \\
\cline { 2 - 3 } & LEV & Leverage (Total liabilities/total assets) \\
\hline
\end{tabular}

The following hypotheses were tested in this study:

$H_{1}$ : There is a relationship between the board size and financial performance in family business.

$\mathrm{H}_{2}$ : There is a relationship between non-executive board member rate in board and financial performance in family business.

$H_{3}$ : There is a relationship between independent board member rate in board and financial performance in family business.

$H_{4}$ : There is a relationship between women board member rate in board and financial performance in family business.

As of September 2019, there are 594 businesses in Borsa Istanbul. 302 of these businesses are financial institutions (banks, insurance companies, leasing and factoring companies, real estate investment trust, 


\section{A. Poroy Arsoy- Y. Ertan - T. Bora Kılınçarslan- O. Bektaş 12/3 (2020) 2531-2542}

securities investment trust, venture capital). Financial institutions are not included in the scope of the research. 189 of 292 businesses other than financial institutions are family businesses. Annual reports, corporate governance compliance reports and websites of 189 family businesses in Borsa Istanbul were examined and information related to the board structure of these businesses were collected. It is determined that the information about the independent members or non-executive members of the board is not included in the annual reports, corporate governance compliance reports and websites of 29 family businesses. 29 family companies have been eliminated from analysis due to missing data. A total of 160 family businesses in Borsa Istanbul which can be reached the number of board members, number of non-executive members, number of independent members and number of women members are included in the scope of the research. The data used in the calculation of the financial performance of the businesses were obtained from the annual reports of the companies, which were published on the Public Disclosure Platform for the period of January $1^{\text {st }}$ December 31 $1^{\text {st }}, 2018$.

In this study, the relationship between the board structures and financial performances of businesses was tested by regression analysis. IBM SPSS Statistics 23 package program was used in the analysis of the data.

\section{FINDINGS}

In this research, which was carried out to determine whether there is a relationship between the board structures and financial performances of family businesses in Borsa Istanbul, descriptive statistics were made primarily for dependent and independent variables. Table 3 presents the results of the descriptive statistics.

Table 3. Descriptive Statistics of Variables ( $\mathrm{n}=160)$

\begin{tabular}{clrrrr}
\hline Variables & \multicolumn{1}{c}{ Acronym } & Mean & Std. Dev. & Max. & Min. \\
\hline \multirow{2}{*}{$\begin{array}{c}\text { Independent } \\
\text { Variables }\end{array}$} & SIZE & 7 & 2,18629 & 15 & 4 \\
\cline { 2 - 6 } & NON-EXE & $74,92 \%$ & 20,14579 & $100 \%$ & $20 \%$ \\
\cline { 2 - 6 } & INDPNT & $31,18 \%$ & 9,46509 & $50 \%$ & $0 \%$ \\
\cline { 2 - 6 } & WOMEN & $16,19 \%$ & 16,01601 & $66,67 \%$ & $0 \%$ \\
\hline \multirow{2}{*}{$\begin{array}{c}\text { Dependent } \\
\text { Variables }\end{array}$} & ROA & 0,04 & 0,12157 & 0,73 & $-0,49$ \\
\cline { 2 - 6 } & ROE & $-0,22$ & 2,70546 & 2,64 & $-24,19$ \\
\cline { 2 - 6 } & ROS & 0,55 & 7,07393 & 88,97 & $-2,75$ \\
\hline
\end{tabular}

As seen in Table 3, the average number of board members was found to be 7 in 160 family businesses traded on the stock exchange. The company with the highest number of members on the board is "Tüpraş-Türkiye Petrol Rafinerileri A.Ş.", belonging to the Koç Group with 15 members. The companies with the least number of members in the board are "Başkent Elektrik Dağıtım A.Ş." and "Mega Polietilen Köpük Sanayi ve Ticaret A.Ş." with 4 members. Considering that the number of board members should be at least 5 according to the CMB Corporate Governance Principles Communiqué, it can be said that these two companies do not comply with this principle.

According to the CMB Corporate Governance Principles Communiqué, the majority of the board members shall consist of non-executive members. The average percentage of non-executive members within the board of directors was found to be 74,92 within the scope of the research. However, the majority of the board members in 22 companies are not non-executive members. In 34 companies, all of the board members are nonexecutive members.

According to the CMB Corporate Governance Principles Communiqué, there shall be independent members among the non-executive board members who have the ability to fulfill their duties impartially. The number of independent board members cannot be less than one third of the total number of board of directors and in any case less than two. In this study, the average percentage of independent members within the board was found to be 31.18. Percentage of independent members within the total board of directors is at most $50 \%$, while 


\section{A. Poroy Arsoy- Y. Ertan - T. Bora Kılınçarslan- O. Bektaş 12/3 (2020) 2531-2542}

5 companies do not have independent board members. In addition, there are fewer than 2 independent board members in a total of 8 companies.

According to the recommended principle of the CMB Corporate Governance Principles Communiqué, the ratio of women members in the board of directors should be at least $25 \%$. In this study, the ratio of women members in the board of directors was found to be $16,19 \%$ on average. The company with the highest ratio of women members within the board of directors is "Orma Orman Mahsulleri Integre Sanayi ve Ticaret A.S.." with $66,67 \%$. There are no women board members in 55 family companies.

In dependent variables, ROA as 0,04 ; ROE as $-0,22 ;$ ROS as 0,55 and LEV as 0,59 was calculated on average.

In this research, Regression Analysis was applied to determine the relationship between family businesses' board structures and financial performance. This research model is formulated as follows:

Financial Performance $(R O A, R O E, R O S, L E V)=\alpha_{0}+\beta_{1}(S I Z E)+\beta_{2}(N O N-E X E)+\beta_{3}(I N D P N T)+\beta_{4}(W O M E N)+\varepsilon$

Table 4. The Relationship between the Board Structures and Financial Performance of Family Businesses

\begin{tabular}{|c|c|c|c|c|c|c|c|}
\hline Financial Performance & Board Structures & $\mathbf{R}^{2}$ & $\mathbf{F}$ & Sig. & Beta & $\mathbf{t}$ & Sig. \\
\hline & SIZE & & & &,- 068 &,- 723 & 471 \\
\hline \multirow[t]{4}{*}{ ROA } & NON-EXE & 0,045 & 1,826 & 0,127 &,- 022 &,- 266 & ,791 \\
\hline & INDPNT & & & &,- 229 & $-2,568$ & 011 \\
\hline & WOMEN & & & &, 035 & ,445 & 657 \\
\hline & SIZE & & & & ,078 & 812 & 418 \\
\hline \multirow[t]{4}{*}{ ROE } & NON-EXE & 0,017 & 0,660 & 0,621 &,- 021 &,- 244 & 807 \\
\hline & INDPNT & & & &,- 007 &,- 073 & ,942 \\
\hline & WOMEN & & & & ,109 & 1,359 & ,176 \\
\hline & SIZE & & & & ,084 & 874 & ,383 \\
\hline \multirow[t]{4}{*}{ ROS } & NON-EXE & 0,026 & 1,022 & 0,398 &,- 114 & $-1,328$ & 186 \\
\hline & INDPNT & & & &,- 062 &,- 687 & 493 \\
\hline & WOMEN & & & &,- 079 &,- 984 & ,326 \\
\hline & SIZE & & & &,- 074 &,- 796 & 427 \\
\hline \multirow[t]{3}{*}{ LEV } & NON-EXE & 0,079 & 3,304 & 0,012 &, 062 & 746 & 457 \\
\hline & INDPNT & & & &,- 295 & $-3,379$ & ,001 \\
\hline & WOMEN & & & & ,001 & -017 & ,987 \\
\hline
\end{tabular}

Table 4 presents a regression model that explains the relationship between family businesses' board structures and their financial performances. Accordingly, the relationship between the board structures of family businesses with ROA $(F=1.826$, sig. $=0.127)$, $\operatorname{ROE}(F=0.660$, sig. $=0.621)$ and $\operatorname{ROS}(F=1.022$, sig. $=0.398)$ were not founded significant because of sig.>0,05. Therefore, it can be stated that there is no significant relationship between the board structures of family businesses and ROA, ROE, ROS. On the other hand, the model between the board structures of family businesses and LEV $(F=3.304$, sig. $=0.012)$ was found significant. Board structures in the model explain 7,9\% of the change in LEV. Accordingly, while only a negative relationship was found between the independent member rate in the board and LEV, there was no statistically relationship between the board size, non-executive member rate, women member rate and leverage. In other words, it can be said that the leverage decreases as the rate of independent members in the board of directors in family businesses increases. In this case, the $\mathrm{H}_{4}$ hypothesis was accepted, and the $\mathrm{H}_{1}, \mathrm{H}_{2}$ and $\mathrm{H}_{3}$ hypotheses were rejected.

\section{CONCLUSION AND DISCUSSION}

Family businesses, both in the world and in our country, are undeniably numerous and form the backbone of the economy. Family businesses that shape the economy need to give importance to corporate governance in order to be sustainable. Corporate governance is a management approach in which the interests of shareholders as well as stakeholders are protected within a fair, transparent, accountable and responsible manner. With good corporate governance practices, in the light of the principles of transparency and accountability, corruption and arbitrary practices in companies decrease and the competitiveness of companies increases. Attention should be given to corporate governance practices in family businesses for the 


\section{A. Poroy Arsoy- Y. Ertan - T. Bora Kılınçarslan- O. Bektaş 12/3 (2020) 2531-2542}

continuity of particularly family businesses for generations. Board of directors play an important role in establishing corporate governance practices in businesses. Therefore, the structure of the boards is also a part of corporate governance practices. In this research, we tried to determine the relationship between the board structures of the family businesses and their financial performances in our country. Within the scope of the regulations regarding the board structures in the CMB Corporate Governance Communiqué, the board size, non-executive member rate, independent member rate and female member rate were taken into account as independent variables, and ROA, ROE, ROS and LEV were calculated regarding financial performance as dependent variables. As a result of the analysis, it has been found that there was no significant relationship between the board structures of family businesses and ROA, ROE, ROS. On the other hand, the model between the board structures of family businesses and LEV $(F=3.304$, sig. $=0.012)$ was found significant. Accordingly, while a negative relationship was found between the independent member rate in the board and LEV, there was no significant relationship between the board size, non-executive member rate, women member rate and leverage. In the other words, it can be said that the leverage decreases as the rate of independent members in the board of directors in family businesses increases.

The findings from this study contain similarities and differences compared to previous studies. In previous studies, while the board size affected the financial performance positively or negatively; in this study, we found that there was no relationship between board size and financial performance. This study determining that there was no relationship between female member rate on the board of directors and financial performance is similar to Kılıç's (2014) study. In this study, while there was no significant relationship between independent member rate and financial performance (ROA, ROE and ROS), Kılıç (2014) and Atılgan (2017) showed that there was a negative relationship between independent member rate and ROA, Şengür and Özbek Püskül (2011) showed that independent member in board have lower ROA and ROE, Ibrahim and Samad (2011) showed that the representation of independent directors in family firms does not improve firm performance, Ling et al. (2016) showed that for on family owned firms, having more independent directors lead to better firm performance. In previous studies, the effect of non-executive members within the board structures on financial performance has not been examined much.

This constraint of this study is family businesses traded on the stock exchange in Turkey. However, there are many family businesses that are not open to the public throughout our country. In the later studies, sample can be taken within the scope of the family business in across Turkey, various studies can be carried out by expanding the independent and dependent variables.

\section{REFERENCES}

Akbank, Deloitte, Sabancı Üniversitesi Yönetici Geliştirme Birimi and TAIDER (2016). Aile şirketlerinde sürdürülebilir başarının anahtarları, https://www2.deloitte.com/tr/tr/pages/risk/articles/the-keys-tosustainable-success-in-the-family-business.html (Date of access: 2 October 2019).

Aktan, C. C. (2013). Kurumsal şirket yönetimi, Organizasyon ve Yönetim Bilimleri Dergisi, 5(1), 150-191.

Al-Ghamdi, M. and Rhodes, M. (2015). Family ownership, corporate governance and performance: Evidence from Saudi Arabia, International Journal of Economics and Finance, 7(2), 78-89.

Ankara Chamber of Industry (2005). Aile şirketleri: Değişim ve süreklilik, https://www.aso.org.tr/kurumsal/media/kaynak/TUR/yayinlarimiz/ailesirketleri.pdf (Date of access: 11 November 2019).

Arosa, B., Iturralde, T. and Maseda, A. (2010). Outsiders on the board of directors and firm performance: Evidence from Spanish non-listed family firms, Journal of Family Business Strategy, 1(4), 236-245.

Athanassiou, N., Crittenden, W. F., Kelly, L. M. and Marquez, P. (2002). Founder centrality effects on the Mexican family firm's top management group: firm culture, strategic vision and goals, and firm performance, Journal of World Business, 37, 139-150.

Atılgan, Ö. (2017). Yönetim kurulu büyüklüğ̈̈, bağımsız üye oranı ve kadın üye oranı ile finansal performans ilişkisi, Dokuz Eylül Üniversitesi İktisadi ve İdari Bilimler Dergisi, 32(2), 315-354. 
A. Poroy Arsoy- Y. Ertan - T. Bora Kılınçarslan- O. Bektaş 12/3 (2020) 2531-2542

Atılgan, Ö. and Aynacı, T. (2016). BIST'te aile işletmelerinin yönetim kurullarında kadın üyeler, Dündar, D. (Ed.), 7. Aile İşletmeleri Kongresi, İstanbul, 14-15 Nisan 2016, İstanbul Kültür Üniversitesi Aile İşletmeleri ve Girişimcilik Uygulama ve Araştırma Merkezi, 297-305.

Avrupa İmar ve Kalkınma Bankası and Nestor Advisors (2018). Türkiye'deki halka açık şirketlerin kurumsal yönetim yapıları ve uygulamaları hakkında araştırma raporu, Sermaye Piyasası Kurulu'na Kurumsal Yönetim İlkelerinin Uygulanması Konusunda Destek Projesi.

Aygün, M., İç, S. and Sayın, C. (2011). Yönetim kurulu büyüklügünü belirleyen faktörler ve yönetim kurulu büyüklüğü ile firma performansı arasındaki ilişki: Türk sermaye piyasası üzerine bir inceleme, Gaziantep Üniversitesi Sosyal Bilimler Dergisi, 10(1), 77-92.

Barry, B. (1975). The development of organization structure in the family firm, Journal of General Management, $3(1), 42-60$.

Carter, D. A., D'Souza, F., Simkins, B. J. and Simpson W. G. (2010). The gender and ethnic diversity of US boards and board committees and firm financial performance, Corporate Governance: An International Review, 18(5), 396-414.

Dalton, D. R., Daily, C. M., Ellstrand, A. E. and Johnson, J. L. (1998). Meta-analytic reviews of board composition, leadership structure, and financial performance, Strategic Management Journal, 19, 269290.

Donckels, R. and Frohlich, E. (1991). Are family businesses really different? European experiences from STRATOS, Family Business Review, 4, 149-160.

Donnelley, R. G. (1964). The family business, Harvard Business Review, 42(3), 93-105.

Erhardt, N. L., Werbel, J. D. and Shrader, C. B. (2003). Board of director diversity and firm financial performance, Corporate Governance, 11(2), 102-111.

Erkan, M. (2012). Türk Ticaret Kanunu'nda Aile İşletmelerinde Kurumsallaşma ve İç Denetim, Bursa, Ekin Basın Yayın Dağıtım.

European Commission (2009). Final report of the expert group - Overview of family-business-relevant issues: Research, networks, policy measures and existing studies.

Family Firm Institute (2017). Global Data Points, https://archive.org/details/perma_cc_CF89-K2JB (Date of access: 15 January 2020).

Georgen, M. and Renneboog, L. (2006). Corporate Governance and Shareholder Value, Lowe, D. and Leiringer, R. (Eds.), Commercial Management of Projects: Defining the Discipline, Blackwell Publishing, 100-131.

Gordini, N. and Rancati, E. (2017). Gender diversity in the Italian boardroom and firm financial performance, Management Research Review, 40(1), 75-94.

Heidrick \& Struggles (2014). Towards Dynamic Governance 2014, European Corporate Governance Report.

Ibrahim, H. and Samad, F. A. (2011). Corporate governance mechanisms and performance of public-listed family-ownership in Malaysia, International Journal of Economics and Finance, 3(1), 105-115.

Kao, M.-F., Hodgkinson, L. and Jaafar, A. (2019). Ownership structure, board of directors and firm performance: evidence from Taiwan, Corporate Governance, 19(1), 189-216.

Karpuzoğlu, E. (2002). Büyüyen ve Gelişen Aile Şirketlerinde Kurumsallaşma, İstanbul, Hayat Yayınları.

Kılıç, M. (2014). Yönetim kurulu yapısının işletme performansına etkisi: Türkiye'de bir uygulama, Muhasebe Bilim Dünyası Dergisi, 3, 33-56.

Kızıltoprak, S. and Aksoy, M. (2018). Borsa İstanbul'da işlem gören aile işletmelerinin finansal performanslarının analizi, Ege Academic Review, 18(1), 135-152.

Lansberg, I. and Astrachan, J. H. (1994). Influence of family relationships on succession planning and training: The importance of mediating factors, Family Business Review, 7(1), 39-59. 
A. Poroy Arsoy- Y. Ertan - T. Bora Kılınçarslan- O. Bektaş 12/3 (2020) 2531-2542

Lee-Kuen, I. Y., Sok-Gee, C. and Zainudin, R. (2017). Gender diversity and firms' financial performance in Malaysia, Asian Academy of Management Journal of Accounting and Finance, 13(1), 41-62.

Ling, W., Jhou, L., Chan, Y., Wang, W., Lin, Y. and Wei, C. (2016). Do corporate governance and social performance differ between family-owned and non-family-owned businesses in Taiwan-Listed CSR companies?, Asian Economic and Financial Review, 6(1), 15-26.

Marimuthu, M. (2008). Ethnic diversity on boards of directors and its implications on firm financial performance, The Journal of International Social Research, 1(4), 431-445.

OECD (2004). OECD Principles of Corporate Governance, https://www.oecd.org/daf/ca/oecd-principlescorporate-governance-2004.htm (Date of access: 5 December 2019).

OECD (2019). OECD Corporate Governance Factbook 2019, http://www.oecd.org/corporate/corporategovernance-factbook.htm (Date of access: 13 February 2020).

Poroy Arsoy, A. and Bora, T. (2015). Relationship Between Corporate Governance and Internal Control, Kurt, G. and Uçma Uysal, T. (Eds.), Holistic Approach to Risk-Based Internal Financial Control for SMEs, Gazi Kitabevi, Ankara, 31-54.

Poutziouris, P., Savva, C. S. and Hadjielias, E. (2015). Family involvement and firm performance: Evidence from UK listed firms, Journal of Family Business Strategy, 6(1), 14-32.

Prencipe, A. and Bar-Yosef, S. (2011). Corporate governance and earnings management in family-controlled companies, Journal of Accounting, Auditing and Finance, 26(2), 199-227.

Saidat, Z., Silva, M. and Seaman, C. (2019). The relationship between corporate governance and financial performance: Evidence from Jordanian family and nonfamily firms, Journal of Family Business Management, 9 (1), 54-78.

Schank, M. J. (2019). Board diversity - determinant of firm's financial performance, Revista Tinerilor Economişti, $33,17-31$.

Spencer Stuart (2019). 2019 Turkey Spencer Stuart Board Index, Sixth edition, https://www.spencerstuart.com/research-and-insight/turkey-board-index (Date of access: 3 March 2020).

SPK (2003). Kurumsal Yönetim İlkeleri.

SPK (2014). Kurumsal Yönetim Tebliğ (II-17.1), 28871 sayılı Resmi Gazete.

SPK (2019). Kurumsal Yönetim Raporlama Rehberi, https://www.spk.gov.tr/Sayfa/Dosya/1297 (Date of access: 18 February 2020).

Şengür, D. E. and Özbek Püskül, A. S. (2011). İMKB kurumsal yönetim endeksindeki şirketlerin yönetim kurulu yapısı ve işletme performansının değerlendirilmesi, Dumlupınar Üniversitesi Sosyal Bilimler Dergisi, 31, 33-50.

TKYD (2009). Kurumsal Yönetim İlkeleri Işığında Aile Şirketleri Yönetim Rehberi, İstanbul, Türkiye Kurumsal Yönetim Derneği Yayınları.

TKYD (2016). BIST Yönetim Kurulları Araştırması 2016, İstanbul, Türkiye Kurumsal Yönetim Derneği Yayınları.

Wellalage, N. H. and Locke, S. (2013). Women on board, firm financial performance and agency costs, Asian Journal of Business Ethics, 2, 113-127.

World Bank (2005), Developing Corporate Governance Codes of Best Practice, Volume I. 